\title{
Loan versus Bond Financing of Czech Compa- nies and the influence of the Global Recession
}

\author{
- Mači Jan, Valentová Hovorková Vladimíra
}

\begin{abstract}
European economies are traditionally considered to be bank based regarding the debt financing. However, in times of crises in the bank sector, this feature may indicate a weakness of these economies when the credit squeeze phenomenon may occur and companies' competitiveness might be negatively affected thanks to unstable financing possibilities. In such conditions, a shift from bank loans to bonds might be expected. That is why this paper focuses on mutual development of corporate bond and business loan markets in the developing Czech economy in the years 2006-2014 with regard to the impacts of the global financial crisis of 2008/2009. The main goal of this article is to identify whether, thanks to the impacts of the global recession in 2009 , there was a shift in Czech economy in business financing from the loans to bonds in a similar fashion as in the case of East Asian economies after their financial crisis in the nineties. Since Czech companies practically do not use short-term bonds, a mutual relationship is examined between amounts of long-term corporate bonds and economic development captured by the GDP per capita, and between long-term business loans and development of long-term corporate bonds. The main findings of this study are that since the global financial crisis, bond financing of businesses has been growing faster than loan financing. Czech economy thus shifts and becomes more bond market-based. The development of bond financing is positively correlated with the GDP per capita. Time series of both loans and bonds develop along the same trend. However, residual components are correlated negatively, which confirms the standing of loans and bonds as substitutes. Two main practical implications may be derived from this study. First, a growing usage of bonds increases demands on the market regulator, especially in the field of monitoring. Second, the growing bond market leads to the increased effectiveness, which makes additional effective sources of finance available to businesses and makes Czech economy more competitive even in times of difficulties in the banking sector.
\end{abstract}

Keywords: corporate finance, corporate governance, liabilities, bonds, loans, financial crisis, recession, capital market development.

JEL Classification: G01, G32, G38.

\section{INTRODUCTION}

Since approximately the eighties of the twentieth century, bond financing has been gaining importance all around the world and it is becoming a rival to its closest substitute, bank loans. The bond financing is a commonly used tool for government financing, being in developed or developing economies. Business financing is different though. While bond financing is considered to be a traditional tool for business financing in the USA, bank loans are mentioned as more traditional and common in Europe, especially in its continental part (De Fiore \& Uhlig, 2005). 
The global economic recession, which originated in the US Great Recession, worsened, among other things, the accessibility of business loan resources in the Czech Republic (Kislingerová et al., 2010). Even well utilized businesses with perspective contracts complained about the worsened conditions for obtaining bank loans and the inability of banks to recognize problematic and perspective business branches. Such conditions, which were additionally stimulated with low base interest rates, provide opportunities for development of other sources of financing. The closest substitute of business bank loans, as sources of external capital, are corporate bonds. Some sources (e.g., Hyblerová, 2014; Miles, 2000) even state that in ideal market conditions, loans and bonds can be considered to be perfect substitutes. The Yoshitomi and Shirai study (2001) states that in the case of Southeast Asia in the ninth decade of the twentieth century, the crisis of the banking sector had a rather strong influence on business financing - a considerable portion of bank loan financing was substituted with bond financing. On the other hand, Cowling, Liu and Ledger (2012) state that in the case of the financial crisis of 2008, or more precisely the global economic recession of 2009, larger and older firms in Great Britain had no major problems with obtaining loans in regard to this crisis.

Because of this, this article focuses on the topic of development of business financing using business loans and corporate bonds in the Czech Republic, including the influence of the period of the global economic recession. The aim of this text is to identify whether a similar shift (from loans to bonds) took place in the Czech Republic following the global financial crisis. Subsequently, using mathematical-statistical methods, it aims to point out whether and how much development of corporate bonds in the Czech Republic depends on economic development expressed by the GDP per capita indicator. A partial aim is also to identify a mutual relationship between loan and bond financing of businesses. This means to, using a mathematical-statistical model, describe mutual development of loan and bond financing of businesses in conditions of the Czech Republic. This relationship may express the standing of loans and bonds as substitutes.

The results, which would prove the ability of Czech economy to switch from loans to bonds and conversely from bonds to loans, may herald Czech financial environment as a less risky territory regarding the banking crises. In other words, Czech companies may finance their businesses smoothly and maintain their competitiveness notwithstanding temporary constraints in banking or capital markets. For example, Greenspan (2000) states that multiple avenues of financial intermediation have served the United States well especially during the credit crunch in 1980s and when the US capital market froze up in 1998 after the Russian default. During those times, the capital market served as a "spare tire" to bank financial intermediation and vice versa. This also may have a beneficial impact on international trade, foreign direct investments, capital flows and overall competitiveness and a relative stability of businesses using bonds as a financial tool as well as loans. On the other hand, the bond market is less regulated than the credit market. Therefore, new challenges may occur for the Czech National Bank that conducts supervision over Czech financial market. 


\section{LITERATURE REVIEW}

Literature states (Braun \& Briones, 2006) that while a whole array of authors focus on development of the capital market as a whole, only a few articles have been published regarding development of the bond market. Regardless, we can find some studies that monitor development of the bond market in the context of certain macroeconomic indicators. For example, Beck, Demirgüç-Kunt and Levine (1999) observe a positive dependence between development of GDP per capita and the volume of emitted bonds in the analyzed sample of economies. Also, there exist multiple approaches to the analysis of mutual relations in development of the loan and bond markets. These relations are usually studied from two points of view. The first one focuses on the demand for bonds, or more precisely, on the supply of loans, which means investors and banks. The second one examines the choice between the loan and bond financing from the perspective of a subject that needs to obtain financial resources. This subject may represent the state, a municipality or a business.

The first approach to loans and bonds is being addressed, for example, by Diamond. His research (see, e.g., Diamond 1984 and 1996) concludes that investors are keener to lend their free financial resources to banks, which subsequently lend them to borrowers, rather than lend them themselves directly if the costs of monitoring of borrowers are too high for the investors. Banks have, in comparison with individual investors, an advantage that they are able to monitor borrowers more efficiently. From the above stated ensues that should an economy have businesses that need to be monitored, it is likely that loan financing, rather than bond financing, will dominate such economy. Hale (2001) states a similar conclusion, even though her approach to the analyzed situation is examined from the perspective of businesses, not investors. The question whether a business, considering a potential state of need, should rather borrow from single or multiple creditors is also an important factor in mutual development of loan and bond markets. This can de facto be a business that stands before the choice between loan and bond financing. Regarding this, Koziol (2006) says that should a business be in financial stringency, but it has got enough projects with a positive current value, it should borrow from a single creditor, as the creditor will not have interest in ending loan financing of the business. If the business is not in financial stringency, however, it should choose financing from multiple creditors. This is apparently caused by what De Fiore and Uhlig (2011) or Altman, Gande and Saunders (2010) mention in introductions of their works. It is the fact that banks have comparative advantage. They have access to internal information about the business, which holders of bonds bought on the capital market do not have.

As stated above, the second point of view on the possibilities of development of loan and bond markets follows the possibilities and motivations of a potential borrower that is a bond issuer, or more precisely, the subject seeking a loan. This article focuses on business financing, which is why there are briefly summarized approaches of businesses to the choice between loan and bond financing in the table 1 below. 
Tab. 1 - Approaches of businesses to the choice between loans and bonds. Source: own

\begin{tabular}{|c|c|c|}
\hline $\begin{array}{l}\text { The choice from } \\
\text { the point of view } \\
\text { of }\end{array}$ & Source & Conclusion \\
\hline $\begin{array}{l}\text { the riskiness of } \\
\text { businesses and } \\
\text { costs of moni- } \\
\text { toring for the } \\
\text { creditor }\end{array}$ & $\begin{array}{l}\text { Hale (2001), } \\
\text { Arena (2011) }\end{array}$ & $\begin{array}{l}\text { Businesses with low risks for the investors will } \\
\text { be financed mainly by using bonds. Medium-risk } \\
\text { businesses will be financed mainly by using loans. } \\
\text { Risky businesses will not have access to loans, } \\
\text { which is why they will be emitting junk bonds. } \\
\text { High-risk businesses will be excluded from both } \\
\text { segments of the market. }\end{array}$ \\
\hline $\begin{array}{l}\text { the accessibility } \\
\text { of loan ratings of } \\
\text { businesses }\end{array}$ & Machnes (2010) & $\begin{array}{l}\text { Businesses with an average-debt quality (measured } \\
\text { by an independent rating of the company) will } \\
\text { not disclose their rating and will rather finance } \\
\text { themselves using loans. Businesses with a high- } \\
\text { debt quality will publish their rating and will be } \\
\text { financed using bonds. }\end{array}$ \\
\hline $\begin{array}{l}\text { the overall eco- } \\
\text { nomic maturity of } \\
\text { the country }\end{array}$ & $\begin{array}{l}\text { Sprčić and Wilson } \\
\text { (2007), Miloš } \\
\text { (2004), Yoshitomi } \\
\text { and Shirai (2001), } \\
\text { Beck et al. (1999) }\end{array}$ & $\begin{array}{l}\text { A sufficient infrastructure for bond emission } \\
\text { exists in developed economies, along with busi- } \\
\text { nesses able to economically utilise bond financ- } \\
\text { ing and an ample reserve of capital. This is why, } \\
\text { in contrast to developing economies, there is a } \\
\text { significant role for bond financing in developed } \\
\text { economies. }\end{array}$ \\
\hline $\begin{array}{l}\text { the size, or phases, } \\
\text { of life cycles of } \\
\text { businesses }\end{array}$ & $\begin{array}{l}\text { Nývltová and } \\
\text { Režňáková (2007), } \\
\text { Hale and Santos } \\
\text { (2008) }\end{array}$ & $\begin{array}{l}\text { In the frame of their life cycles, businesses usu- } \\
\text { ally first choose loan financing and only in later } \\
\text { stages, move to bond financing. }\end{array}$ \\
\hline $\begin{array}{l}\text { the communica- } \\
\text { tion of businesses } \\
\text { with the investor } \\
\text { community }\end{array}$ & $\begin{array}{l}\text { Užík and Šoltés } \\
(2009), \text { Meluzín } \\
\text { (2008), Meluzín } \\
\text { and Zinecker } \\
\text { (2009) }\end{array}$ & $\begin{array}{l}\text { Rating, which is linked to emission of bonds, } \\
\text { gives businesses an additional marketing tool for } \\
\text { communication with investor and creditor com- } \\
\text { munities. A business may even increase awareness } \\
\text { of the company; not only towards the current, but } \\
\text { more importantly towards the potential suppliers } \\
\text { and customers. }\end{array}$ \\
\hline $\begin{array}{l}\text { the terms of the } \\
\text { loan contract }\end{array}$ & $\begin{array}{l}\text { Hale (2005), } \\
\text { Renaud (2014), } \\
\text { Smith (2014) }\end{array}$ & $\begin{array}{l}\text { Banks, in order to contain risks, implement vari- } \\
\text { ous limiting conditions in their loan contracts. } \\
\text { Such constraints protect the banks, but restrict } \\
\text { businesses. This is why sufficiently experienced } \\
\text { management of a business, who consider such re- } \\
\text { strictive constraints too limiting, will rather prefer } \\
\text { bond financing over loans. }\end{array}$ \\
\hline
\end{tabular}


The analytic part of this article has mainly been inspired by Beck, Demirgüç-Kunt and Levine's work (1999), where this author follows the relationship of development of the bond market in connection to development of GDP per capita. Beck states that the development of the bond market is positively correlated with the development of GDP per capita. Simply speaking, the wealthier population and companies are the larger amount of bonds are demanded and issued. Contesi, Li and Russ (2013) analyzed correlations between the growth rates of a real GDP and the real bank loans, respectively, real bonds in the US market. Their finding is that loans are more procyclical than bonds. The second study, on which this article is mainly based, is work of Yoshitomi and Shirai (2001), who analyzed development of the bond market in connection to the crisis in the South Asia region in the ninth decade of the twentieth century. Based on the data they analyzed, it is clear that one of the outcomes of the Asian financial crisis is rather strong shift of businesses from bank loans to bond financing. Yoshitomi and Shirai also conclude that "policies should place less emphasis on bank loans and more on developing domestic corporate bond markets as alternative sources of debt financing" (p. 66). At the same time, these authors state differences between developing and developed economies in the area of business financing using loans and bonds. We can state that businesses in developing countries are more reliant on loan financing, while bond financing is more prevalent in developed economies (see Fig. 1).

\begin{tabular}{|c|c|}
\hline Developing Countries & Developed Countries \\
\hline \multicolumn{2}{|c|}{ Features of Investors and Borrowers } \\
\hline $\begin{array}{l}\text { Low income level and limited asset ac- } \\
\text { cumulation }\end{array}$ & $\begin{array}{l}\text { High income level and ample asset ac- } \\
\text { cumulation }\end{array}$ \\
\hline$\nabla$ & $\nabla$ \\
\hline $\begin{array}{l}\text { - High demand for liquidity and bank } \\
\text { deposits, } \\
\text { - underdeveloped insurance and } \\
\text { pension industries, } \\
\text { - large number of SMEs. }\end{array}$ & $\begin{array}{l}\text { Demand for diversified asset } \\
\text { portfolio, } \\
\text { - developed insurance and pension } \\
\text { industries, } \\
\text { - large number of large, reputable } \\
\text { firms. }\end{array}$ \\
\hline \multicolumn{2}{|c|}{ Extent of Information Asymmetry } \\
\hline Very high & Lower \\
\hline \multicolumn{2}{|c|}{ Nature of funding } \\
\hline $\boldsymbol{\nabla}$ & $\nabla$ \\
\hline Bank-based & Bond market-based \\
\hline
\end{tabular}

Fig. 1 - Phases of economic and financial system development and formation of business financing. Source: own, based on Yoshitomi and Shirai (2001) 


\section{DATA AND METHODOLOGY}

Within this article, mutual development of business loans and corporate bonds in Czech economic environment is being analyzed. The necessary data concerning volumes of business loans and corporate bonds have been obtained via the ARAD time series database from the Czech National Bank (CNB). In case of bank loans, CNB collects data from the banks and foreign bank branches operating in the Czech Republic (except CNB). The figures represent final balances of loan accounts (which is initial balance plus drawing of a new loan minus instalment of previously provided loans). In case of bonds, the number represents the final balance of a particular period (initial balance plus newly issued bonds minus payed up volume). There are included all issues of the Czech non-financial corporations that issue bond on Czech market or abroad in all currencies converted to CZK. When processing this article parallel data for both time series, these were only available for the years 2006-2014, as CNB has only published the bond statistics since 2006 and the data for 2015 were unavailable during the data collection for this study. In case of the bonds from the category of non-financial businesses, only data from 31 December of each particular year, i.e. in yearly intervals, are available. This means that each time series contains 9 observations. At the same time, only time series of long-term loans and long-term bonds are being analyzed, as short-term bonds are practically never used by Czech businesses. The only exception in the usage of short-term bonds has so far been the Czech power company ČEZ, which issued such securities in 2013. Not only because of absence of usage of short-term bonds, but also thanks to the fact that long-term and short-term debts develop in different ways, short-term loans provided to non-financial businesses were excluded from comparison of loan and bond financing.

For the purposes of the analysis of dependence between GDP per capita and development of bond financing, the data regarding development of GDP per capita were adopted from the Czech Statistical Office (CZSO). Both the bond time series and the GDP per capita time series are observed in CZK. Even in this case, the accessibility of data regarding development of bond financing is a limiting factor in number of observations.

Figures regarding development of both GDP per capita and usage of long-term loans and longterm bonds by businesses in the Czech Republic are captured in the following table 2 .

Tab. 2 - The development of GDP per capita and volumes of corporate bonds and loans.

Source: own, based on data from CNB and CZSO

\begin{tabular}{|l|c|l|l|l|l|}
\hline Year & \multicolumn{1}{|c|}{2006} & \multicolumn{1}{c|}{2007} & \multicolumn{1}{c|}{2008} & \multicolumn{1}{c|}{2009} & \multicolumn{1}{c|}{2010} \\
\hline GDP per capita (CZK) & $341,604.36$ & $\begin{array}{l}371,203.57 \\
(+8.66 \%)\end{array}$ & $\begin{array}{l}384,991.81 \\
(+3.71 \%)\end{array}$ & $\begin{array}{l}373,810.23 \\
(-2.90 \%)\end{array}$ & $\begin{array}{l}375,920.71 \\
(+0.56 \%)\end{array}$ \\
\hline $\begin{array}{l}\text { Sum of corporate } \\
\text { bonds (mil. CZK) }\end{array}$ & $92,525.46$ & $\begin{array}{l}75,469.71 \\
(-18.43 \%)\end{array}$ & $\begin{array}{l}81,898.33 \\
(+8.52 \%)\end{array}$ & $\begin{array}{l}129,715.73 \\
(+58.39 \%)\end{array}$ & $\begin{array}{l}172,556.18 \\
(+33.03 \%)\end{array}$ \\
\hline $\begin{array}{l}\text { Sum of corporate loans } \\
\text { (mil. CZK) }\end{array}$ & $246,428.80$ & $\begin{array}{l}285,982.30 \\
(+16.05 \%)\end{array}$ & $\begin{array}{l}345,126.00 \\
(+20.68 \%)\end{array}$ & $\begin{array}{l}360,171.50 \\
(+4.36 \%)\end{array}$ & $\begin{array}{l}391,252.20 \\
(+8.63 \%)\end{array}$ \\
\hline
\end{tabular}




\begin{tabular}{|l|l|l|l|l|}
\hline Year & \multicolumn{1}{|c|}{2011} & \multicolumn{1}{c|}{2012} & \multicolumn{1}{c|}{2013} & \multicolumn{1}{c|}{2014} \\
\hline \multirow{2}{*}{ GDP per capita (CZK) } & $\begin{array}{l}383,208.13 \\
(+1.94 \%)\end{array}$ & $\begin{array}{l}385,152.24 \\
(+0.51 \%)\end{array}$ & $\begin{array}{l}388,770.74 \\
(+0.94 \%)\end{array}$ & $\begin{array}{l}405,342.41 \\
(+4.26 \%)\end{array}$ \\
\hline $\begin{array}{l}\text { Sum of corporate } \\
\text { bonds (mil. CZK) }\end{array}$ & $198,696.51$ & $278,916.27$ & $310,738.91$ & $340,368.91$ \\
\hline $\begin{array}{l}\text { Sum of corporate loans } \\
\text { (mil. CZK) }\end{array}$ & $419,058.90$ & $424,305.60$ & $448,011.30$ & $465,603.80$ \\
\hline
\end{tabular}

Note: Relative annual changes are stated in brackets under absolute values.

Based on the aims stated in the introduction of this article, two research questions and two hypotheses were established.

RQ1: Is there a shift in financing strategies of businesses from loans to bonds in the observed time period?

RQ2: Is there a negative relationship between development of loan and bond financing?

H01: Development of corporate bond financing does not depend on development of GDP per capita.

H02: Development of loan financing does not depend on development of bond financing.

The first research question can be answered using basic tools of descriptive statistics. The second research question (RQ2) is expanded into the H02 hypothesis. In case of the second research question, or the second hypothesis, revealing the rate at which loans and bonds can be substituted is expected. Since it is generally said that bank loans are the traditional tool for business financing in the Czech Republic, while bonds are not (see, e.g., Strýčková and Hojná (2013)), development of bond financing is set to be an independent variable, whereas development of loan financing is set to be a dependent variable. The first hypothesis is supposed to verify, in case of the Czech Republic, a positive relationship between development of GDP per capita (an independent variable) and development of bond financing (a dependent variable), as it is observed by Beck, Demirgüç-Kunt and Levine (1999) in the case of other market oriented economies.

In order to prove or reject the above-stated research hypotheses, we examined correlation using Pearson's correlation coefficient between two time series with the program Statgraphics. When examining the relationship between time series, there is a risk of

a so-called autocorrelation. The autocorrelation means that two time series do not influence each other but there exists another common factor or factors that influence both of them in the same way. In order to avoid such mistake in interpretation, we examined the Durbin-Watson test of autocorrelation.

All indicators come from a normal distribution. It was verified with the help of Shapiro- Wilk test for normality. The P-Value for Sum of corporate bonds is 0.264 , for GDP per capita 0.244 and for sum of corporate loans 0.605 . 


\section{RESEARCH RESULTS}

The research first focused on answering the first research question, i.e. whether or not there is a shift in financing strategies of businesses from loans to bonds in the Czech Republic in the observed time period between the years 2006 and 2014. The essential information is apparent from the following chart (Fig. 2), which is based on the data from Tab. 2.

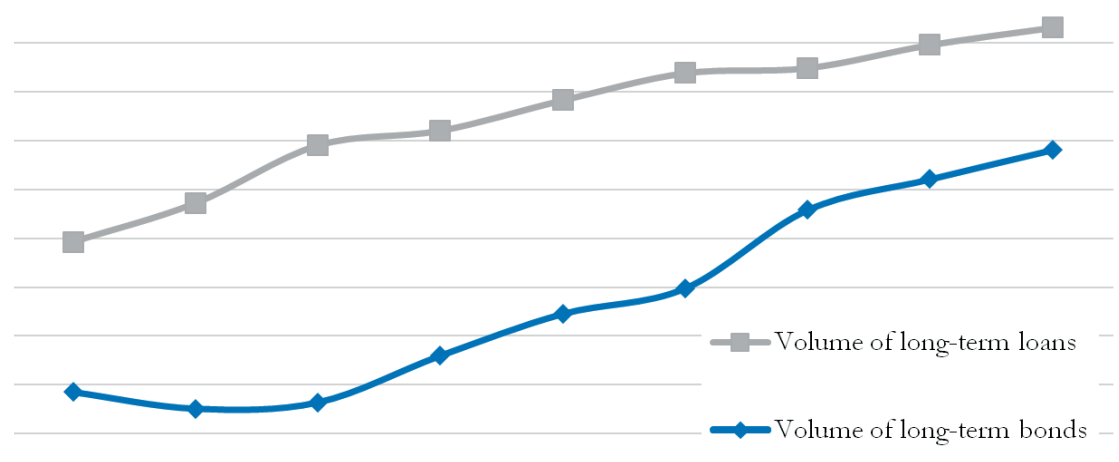

Fig. 2 - The development of total volume of long-term corporate loans and bonds in the Czech Republic in the years 2006-2014 (mil. CZK). Source: own, based on the data from CNB

It is clear from the chart (Fig. 2) that both loan and bond financing grew throughout almost the entire observed time period. At the same time, it can be stated that the share of bonds in longterm debt financing increased, as bond financing grew faster. The gap between both curves reached its peak in 2008 (263,227.67 mil. CZK). Since then, it rather has got a tendency to close. By the end of the year 2014, the gap between loans and bonds amounted only to 125,234.89 mil. CZK. During the whole time series, loans increased by 219,175.00 mil CZK (+88.94\%) and bonds increased by 247,843.45 mil. CZK (+267.87\%). Taken in absolute volumes, a slightly larger increase is evident in bond financing over loan financing during the years 2006 and 2014. In terms of relative figures, a more progressive development can be observed in bond financing. A larger ratio of using bonds may be partially caused by the impact of the global financial crisis in Czech setting, where banks, to a certain degree, toughened up conditions for obtaining loans (see Kislingerová et al., 2010). Emitting bonds allows businesses to become independent on banks and their will to provide financial means in the form of loans. Another reason for the increased rate of using bonds may be a change in Czech Act No. 190/2004 Coll., on Bonds from 2012, which lowered regulatory requirements for bond emission. This legislative change cannot explain the years 2006-2011 though. On the other hand, it may, at least partially, explain a significant increase in bond financing in 2012. The real impact of individual considered factors can be, however, established only through a more detailed research using questionnaire surveys.

The first research question can be, based on the above, answered by saying that in Czech setting, there is a certain shift in financing strategies of businesses that manifests by an increased usage of bonds. 


\subsection{Development of bond financing in relation to development of GDP per capita}

Development of bond financing can be observed in relation to various markers. The macroeconomic marker of GDP per capita, which was, for example, analyzed in relation to bonds by Beck, Demirgüç-Kunt and Levine (1999), seems to be a relevant one. If there is an increase in products per person in economy, savings and investments should increase as well. The resulting increased demand for securities from investors makes the capital market more efficient (Beck, DemirgüçKunt, \& Levine 1999). This makes bond financing more accessible, i.e. economically usable for a growing number of economic subjects. If the Czech Republic is a standard developing economy, then even here a positive correlation between development of GDP per capita (an independent variable) and development of bond financing (a dependent variable) should exist. The null and the alternative hypotheses are as follows:

H01: Development of corporate bond financing does not depend on development of GDP per capita.

H11: Development of corporate bond financing depends on development of GDP per capita. The results of the correlation analysis of time series from Tab. 2 are stated in the following table (Tab. 3).

Tab. 3 - Results of the correlation analysis of time series (bonds vs. GDP per capita 20062014). Source: own

\begin{tabular}{|c|c|c|c|}
\hline Parameter & Least Squares Estimate & T Statistic & P-Value \\
\hline Intercept & $-1.40 * 10^{\wedge} 6$ & -2.34694 & 0.0513 \\
\hline Slope & 4.19774 & 2.66159 & 0.0324 \\
\hline & F-Ratio & P-Value & \\
\hline Analysis of Variance & 7.08 & 0.0324 & \\
\hline
\end{tabular}

Correlation coefficient: 0.709214

R-squared: 50.2984 percent

Durbin-Watson: $0.961891(\mathrm{P}=0.0169)$

Bonds $=-1.40374 * 10^{6}+4.19774 *$ GDP per capita

The analysis of variance says that, for the particular model on the level of significance $\alpha=5 \%$, a statistically significant dependence exists between development of bond financing and development of the GDP per capita marker ( $\mathrm{p}$-value $=0.0324<\alpha=0.05$ ). The null hypothesis (H01) is thus rejected and the $\mathrm{H} 11$ is accepted. The model explains $50.30 \%$ of variability of the dependent variable. The correlation coefficient indicates a rather strong relationship between the variables. At the same time, however, the value of Durbin-Watson test lies in an area where the test is not definite. This is why a mutual independence of residues was measured using a test of null value of the correlation coefficient. The result of the test, on the level of significance $\alpha=5 \%$, confirmed the existence of a linear dependence between the residues. The dependence is indirect and fairly strong. Based on the performed tests, the correlation between both time series is not considered to be just illusory. Both variables are mutually correlated. The model can thus be interpreted in the way that should GDP per capita increase by 1 CZK, bond financing will, on average, increase by 4.19 mil. CZK. 
The above confirms previous Beck, Demirgüç-Kunt and Levine's research (1999) performed in other economies. Simultaneously, a higher determination index value can be expected in normal periods. The low value (50.30\%) can be in this case probably caused by external influences (e.g., the impact of the global financial crisis on economic development, or, in case of the bonds, the change of legislature).

Based on Tab. 3, it also follows that on the level of significance $\alpha=5 \%$, the intercept point with the vertical axis can be considered statistically insignificant. This also reflects economic reality where, given zero GDP per capita, there can be no negative volume of bonds. The intercept point with the vertical axis can thus be excluded from the equation. The tested hypotheses remain unchanged. The results of the statistical analysis are in this case as follows (see Tab. 4):

Tab. 4 - Results of the correlation analysis of time series (bonds vs. GDP per capita 2006-2014) with the exclusion of the intercept point of the y-axis. Source: own

\begin{tabular}{|c|c|c|c|}
\hline Parameter & Least Squares Estimate & T Statistic & P-Value \\
\hline Slope & 0.499732 & 5.91153 & 0.0004 \\
\hline & F-Ratio & P-Value & \\
\hline Analysis of Variance & 34.95 & 0.0004 & \\
\hline
\end{tabular}

Correlation coefficient: 0.902064

R-squared: 81.372 percent

Durbin-Watson: 0.185889

Bonds $=0.499732 *$ GDP per capita

When looking at the results of the analysis of variance, it can be stated that on the level of significance $\alpha=5 \%$, we reject the null hypothesis regarding independence of bond financing on development of GDP per capita and we accept the alternative hypothesis. The correlation coefficient points at strong dependence. The index of determination says that $81.37 \%$ of the dependent variable is expressed by the particular model, i.e. by a line. After excluding the statistically insignificant intercept point with the y-axis, the slope of the line changes rather markedly. The model can now be interpreted in the way that an increase in GDP per capita of $1 \mathrm{CZK}$ will, on average, mean an increase in bond financing of businesses of approximately 0.5 mil. CZK. Different values of slopes of models of lines with and without the intercept point hint at feasibility of a different model. Based on testing, the " $\mathrm{Y}=\mathrm{e}^{\wedge}\left(\left(\mathrm{b} \_1 \sqrt{\mathrm{x}}_{\mathrm{x}}\right)\right)$ " function or an exponential function seem like more suitable models. Both cases show practically the same, a very high correlation coefficient (0.999) and index of determination (99.87\%).

Should the (pre)crisis period be excluded and the time series starts by the year the global financial crisis had the largest impact on Czech economy (i.e., the year 2009), then the analysis shows somewhat different results (see Tab. 5). The statistical hypotheses are unchanged.

Tab. 5 - Results of the correlation analysis of time series (bonds vs. GDP per capita 20092014). Source: own

\begin{tabular}{|c|c|c|c|}
\hline Parameter & Least Squares Estimate & T Statistic & P-Value \\
\hline Intercept & $-2.32 * 10^{\wedge} 6$ & -3.68237 & 0.0212 \\
\hline
\end{tabular}




\begin{tabular}{|c|c|c|c|}
\hline Slope & 6.64032 & 4.06222 & 0.0153 \\
\hline & F-Ratio & P-Value & \\
\hline Analysis of Variance & 16.5 & 0.0153 & \\
\hline
\end{tabular}

Correlation coefficient: 0.897159

R-squared: 80.4893 percent

Durbin-Watson: $1.80861(\mathrm{P}=0.1896)$

Bonds $=-2.32051 * 10^{6}+6.64032 *$ GDP per capita

This time, the line model capturing the relationship between GDP per capita and bonds describes the situation quite precisely. The analysis of variance states that on the level of significance $\alpha=5 \%$, the H01 can be rejected and the H11 accepted. The P-value of the Durbin-Watson test is greater than 0.05 , the null hypothesis of independence of residues is not rejected. This means that a serial autocorrelation is not identified. Simultaneously, the model explains $80.49 \%$ of variability of the dependent variable. This is, in contrast to the previous situation where the same time series of the years 2006-2014 were tested, a value approximately by 30 percentage points greater. This difference points at a significant influence of the global financial crisis and the following economic recession. The correlation coefficient indicates a very strong relation between the variables.

The tested line model states that if GDP per capita increases by $1 \mathrm{CZK}$, then bond financing increases, on average, by $6.64 \mathrm{mil}$. CZK. There is not much sense in this case in interpreting the intercept point with the y-axis, as it would say that, given zero GDP per capita, bond financing would be negative, which is an unattainable state. On the other hand, the y-intercept point also indicates that bond financing should exist only after reaching certain level of GDP per capita (an intercept point with the x-axis), which actually may describe a real situation. For example, based on the "packing order model" theory (see, e.g., Myers, 1984) and a financing model of businesses in relation to their life cycle, businesses use their own sources of financing and only then use debt resources. Bonds are even used in a later life cycle stage of a business than loans.

Even this result of a correlation of time series must be treated with caution, however, especially due to rather short time series that it relates to. Going forward, it is advisable to monitor the time series further and, thanks to new observations, make the results more precise. Should the Czech economy develop in a similar direction as so far, however, it can be expected that even on a longer-time series, a positive development of business bond financing in relation to positive development of the economy will be confirmed.

\subsection{The mutual relationship between development of loan and bond financing}

The next step in the analysis of secondary data is verification of the thesis that loans and bonds are substitutes (as per, for example, Miles (2000, p. 222) or Hyblerová (2014)). Considering a fixed need for debt financing, this would mean that if there is an increase in loans, bonds must decrease, and vice versa. If the overall need for debt financing grows, then it means that an increase in loans will slow down the growth of bonds, and vice versa.

In this situation, the aim is to determine whether one kind of financing is independent on the other one. Given the fact that the overall volume of long-term debts increases in the observed period, it may be assumed that development of bonds will, more likely than not, slow down 
development of loans (it will not just substitute them). The opposite view is also possible. That is, development of loans will slow down development of bonds. Even though development of both time series is being observed and both variables, taken from the perspective of the statistical analysis, may thus figure in the role of either the interpretive or interpreted variable, bonds were chosen as the independent (interpretive) variable and loans as the dependent (interpreted) variable. This assumption results from the fact that Czech bond market of corporate bonds is, above all, younger, but also smaller in volume, while the loan market is already established and traditional. The hypotheses are now laid down as follows:

H02: Development of loan financing does not depend on development of bond financing.

H12: Development of loan financing depends on development of bond financing.

The tested model was, as in the previous case, a line. The results of the statistical analysis of two above-mentioned time series (see Tab. 2) are marked in Tab. 6.

Tab. 6 - Results of the correlation analysis of time series (loans vs. bonds 2006-2014). Source: own

\begin{tabular}{|c|c|c|c|}
\hline Parameter & Least Squares Estimate & T Statistic & P-Value \\
\hline Intercept & 255,564 & 9.80383 & 0.0000 \\
\hline Slope & 0.646113 & 5.20622 & 0.0012 \\
\hline & F-Ratio & P-Value & \\
\hline Analysis of Variance & 27.1 & 0.0012 & \\
\hline
\end{tabular}

Correlation coefficient: 0.891487

R-squared: 79.475 percent

Durbin-Watson: $0.907763(\mathrm{P}=0.0073)$

Loans $=255,564+0.646113 *$ Bonds

The output shows that the chosen model (a line) describes the relation between loans and bonds quite precisely. The analysis of variance says that on the level of significance $\alpha=5 \%$, it is possible to reject the null hypothesis and accept the alternative one. In other words, there is a statistically significant relation between loans and bonds. Next, it may be stated that $79.475 \%$ of variability of the dependent variable can be described by the particular model. The correlation coefficient equals 0.89 and indicates a very strong relation between the variables. The value of the tested criterion of the Durbin-Watson test lies in an area where the test is not definite. The subsequent measurement of mutual dependence of residues using a test of null value of the correlation coefficient proved, on the level of significance $\alpha=5 \%$, a strong indirect linear dependence. This leads to conclusion that the observed correlation between both time series is not just illusory. Emission of bonds influences development of loan financing. The model says that should longterm bond financing increase by 1 mil. CZK, long-term loan financing of businesses increases, on average, by 0.646 mil. CZK. An aggregate regression line acquired by switching the dependent and independent variables would say that should the loans increase by 1 mil. CZK, the corporate bonds would, on average, increase by 1.231 mil. CZK. A higher preference for long-term bonds over long-term loans is thus noticeable in businesses in the particular time series.

Based on the index of determination, which reaches a rather high value, it may be deduced that 
the chosen model can be considered of a good quality. Random influences, such as for example, the change of legislature in case of bonds, or the change in regulation of the banking sector made in reaction to the global financial crisis in case of loans, may speak against this high value though.

Based on the tested model, it also follows the structure that if bond financing increases, loan financing increases as well, albeit slower. This speaks against the logic and argumentation of the statement that loans and bonds are mutual substitutes. The main trend may thus probably be explained, in case of both time series, by some other mutual interpretive variable. Macroeconomic development, expressed by, e.g., a change in GDP or a change in base interest rates in the economy, seems like a possible candidate in this case. On the other hand, as mentioned in the previous paragraph, residues of both time series develop in opposite directions, which is something that probably does signalize a relationship between loans and bonds as substitutes.

In order to have a negative correlation to be observable even in the main trend of both time series, loans would have to, fundamentally, lose their competitive position in regard to bonds, or vice versa. Such a situation may be possible in case of loans during a long-lasting bank crisis or due to an increased regulation of the banking sector, or, in case of bonds due to a larger change in legislature or lowered costs of bond emission and monitoring of borrowers.

\section{LIMITING FACTORS OF THE RESEARCH}

The basic limiting factor of the research is a rather short available time series of data regarding development of corporate bonds in the Czech Republic. The research thus so far contains only 9 observations. The impact of this limiting factor is visible also when comparing results with a previous similar study (Mačí, 2015) that did not include the data from the year 2014, which were not available at that time.

In case of the analysis of a relationship between development of GDP per capita and development of the volume of corporate bonds, the findings are further burdened with at least two or three more or less one-off events. The first event is the global financial crisis. The aggregate market data seem to indicate that development of GDP per capita was negatively affected by the crisis, while development of bond financing of businesses was affected positively. Whether the inter-year bond development changes of 2008/2009 (+58.39\%) and 2009/2010 (+33.03\%) can really be explained by the impacts of the global financial crisis can be verified only through a questionnaire survey on a relevant sample of respondents. The second and third events are legislature amendments. The first amendment is that of Czech Act No. 190/2004 Coll., on Bonds from 2012, which significantly simplified bond emission and also abolished supervision of the Czech National Bank. The second amendment, which probably influenced development of bond usage, is that of Czech Act No. 586/1992 Coll., on Income Taxes. This amendment disallowed optimization of taxes down to $0 \mathrm{CZK}$ in so-called one-crown bonds, meaning bonds with a nominal value of 1 CZK, issued since January 1 2013, which had been allowed till then. A marked interyear increase in the overall amount of bonds issues in the year 2012, which may be a result of the above-mentioned amendments, is, after all, visible even in Tab. $2(2011 / 2012+40.37 \%)$. It is also obvious that development of the bond market cannot be explained by using development of 
the GDP per capita marker only. It would be appropriate to include other relevant interpretive variables in the model as well, for example, development of interest rates in the economy. Even such a model would not include an inner motivation of businesses to use corporate bonds. Such missing qualitative information may only be acquired using questionnaire surveys. The notion of insufficient model complexity may also be applied to the mutual relation between loan and bond financing of businesses.

In case of the analysis of mutual development of loans and bonds, apart from the above-mentioned amendments, the fact that only long-term loans were analyzed in the time series can, in particular, be considered one of the limiting factors. Should, for example, due to a decrease in market interest rates, a time substitution take place, that is a substitution in the direction from short-term loans to long-term bonds, the analysis would not explain such an actuality.

\section{CONCLUSIONS AND DISCUSSION}

This article mainly proposes identifying whether bond financing was more significantly used in Czech economy after the impact of the global financial crisis of 2009. This is exactly what, for example, happened in Asian economies after their financial crisis in the second half of the nineties (Yoshitomi \& Shirai, 2001). Partial aims laid especially in identification of closer relationships between development of GDP per capita and bond financing, as well as between loan and bond financing of businesses. Since Czech companies practically do not use short-term bonds, this research was based on the analysis of long-term loans and bonds.

As far as the main research goal is concerned, a rather significant increase in bond financing of businesses can be observed in the aggregated data for Czech economy after the year 2009. This observed phenomenon heralds certain ability of Czech companies to switch between loans and bonds and thus at least maintain continuity in production processes (in fact competitiveness) even in times of difficulties in the banking sector. In other words, Czech companies are in a certain way able to use what Greenspan (2000) calls "spare tire". In the analyzed period, that is in the years 2006-2014 (the data for 2015 were unavailable during the processing of this article), the volume of issued long-term corporate bonds expressed in CZK increased by $267.87 \%$. This amounts to an average annual increase of $17.68 \%$. The share of bond financing on the overall long-term debt financing (i.e., long-term loans + long-term bonds) also grows significantly. Considering lower dynamics of development of business loans, it can be stated that there is a certain shift in business financing from loans to bonds in the Czech Republic following the global financial crisis. However, contrary trend is not as noticeable as in case of the US loan and bonds markets (see Contesi, Li and Russ (2013)).

Furthermore, the research confirmed that there exists a statistically significant relation between development of GDP per capita and development of corporate bonds in Czech economy. This relation was presumed based on Beck, Demirgüç-Kunt and Levine's study (1999). Both time series are strongly positively correlated. If the mutual relation is expressed by an exponential function, the model actually explains $99 \%$ of variability of the dependent variable. A serial autocorrelation based on the test of null value of the correlation coefficient of residues would be rejected if there was a very strong negative correlation between the residues on the $5 \%$ level of 
significance. This means that while the main trend is similar in both time series, both time series develop in opposite directions in case of the residual component. This may be caused by the fact that even though GDP per capita declines in the recession period, long-term debts are not sensitive to short-term fluctuations in the economy. Conversely, businesses do not have an increased need to use bond financing in the conjuncture period.

Based on the analysis of relationship between the volume of business loans and corporate bonds, two conclusions may be deduced. First, the overall data show that development of business loans and long-term corporate bonds is positively correlated. Since the loans and bonds are de facto substitutes, in ideal market conditions even ideal substitutes, this relation may probably be clarified by using a different mutual independent variable. In this point of view, bonds and loans are rather complementary to each other. However, when analyzing residues, a statistically important negative correlation, which can be explained by mutual standing of loans and bonds as substitutes, can be observed between both time series. This proves what Hyblerová (2014) or Miles (2000) state.

This article provided basic findings regarding quantitative development of long-term corporate bonds the in the years 2006-2014 not only in relation to development of GDP per capita, but also in relation to development of long-term business loans. Certain emphasis was put on the global financial crisis as a potential initiator of the change in financing strategy of businesses using loans, or bonds. The qualitative data regarding development of business loans and bonds with the emphasis on the global financial crisis can be obtained using questionnaire surveys. This has already been done by the authors of this article and the data are currently being processed.

\section{References}

1. Altman, E. I., Gande, A., \& Saunders, A. (2010). Bank Debt versus Bond Debt: Evidence from Secondary Market Prices. Journal of Money, Credit and Banking, 42 (4), 755-767. http:// dx.doi.org/10.2139/ssrn.639081

2. Arena, M. (2011). The corporate choice between public debt, bank loans, traditional private debt placements, and 144A debt issues. Review of Quantitative Finance and Accounting, 36 (3), 391-416. http://dx.doi.org/10.1007/s11156-010-0182-3

3. Beck, T., Demirgüç-Kunt, A., \& Levine, R. (1999). A New Database on Financial Development and Structure (World Bank Policy Research Working Paper No. 2146). New York: The World Bank, Development Research Group. Retrieved March 10, 2014 from http://papers.ssrn. com/sol3/papers.cfm?abstract_id=615009

4. Braun, M., \& Briones, I. (2006). The Development of Bond Markets around the World (working paper). Santiago: Universidad Adolfo Ibáñez. Retrieved December 20, 2014 from http:// www.iadb.org/res/laresnetwork/files/pr268finaldraft.pdf

5. CNB. (2016). AR AD data series system [data files]. Retrieved from: http://www.cnb.cz/docs/ ARADY/HTML/index_en.htm

6. Contesi, S., Li, L., \& Russ, K. (2013). Bank vs. Bond Financing Over the Business Cycle. Economic SYNOPSES, 31. Retrieved from: https://research.stlouisfed.org/publications/ es/13/ES_31_2013-11-15.pdf 
7. Cowling, M., Liu, W., \& Ledger, A. (2012). Small business financing in the UK before and during the current financial crisis. International Small Business Journal, 30 (7), 778-800. http:// dx.doi.org/10.1177/0266242611435516

8. CZSO. (2016). Hlavni makroekonomické ukazatele [data file]. Retrieved from: https://www. czso.cz/csu/czso/hmu_cr

9. Diamond, D. W. (1984). Financial Intermediation and Delegated Monitoring. Review of Economic Studies, 51 (3), 393-414

10. Diamond, D. W. (1996). Financial Intermediation as Delegated Monitoring: A Simple Example. FRB Richmond Economic Quarterly. 82 (3), 51-66

11. Fiore, D. De, \& Uhlig, H. (2005). Bank. Finance versus Bond Finance. What Explains the Differences between US and Europe? (Working Paper Series No. 547). Frankfurt am Mein: European Central Bank, November 2005

12. Fiore, D. De, \& Uhlig, H. (2011). Bank Finance versus Bond Finance (NBER Working Paper Series No. 16979). Cambridge, MA: National Bureau of Economic Research, April 2011

13. Greenspan, A. (2000). Remarks by Chairman Alan Greenspan. Global challenges. Retrieved from http://www.federalreserve.gov/boarddocs/speeches/2000/20000712.htm

14. Hale, G. (2001). Bonds or Loans? On the Choice of International Debt Instrument by Emerging Market Borrowers. Berkeley (CA): UC Berkeley, 14 November. Retrieved September 23, 2015 from http://aida.econ.yale.edu/ gh79/jmp.pdf

15. Hale, G. (2005). Bonds or Loans? The Effect of Macroeconomic Fundamentals (Working Paper No. 257). Stanford Center for International Development, September. Retrieved September 23, 2015 from http://scid.stanford.edu/sites/default/files/publications/257wp.pdf

16. Hale, G., \& Santos, J. A. C. (2008). The decision to first enter the public bond market: The role of firm reputation, funding choices, and bank relationships. Journal of Banking \& Finance, 32 (9), 1928-1940. http://dx.doi.org/10.1016/j.jbankfin.2007.12.016

17. Hyblerová, Š. (2014). Bond Issue as a Source for Financing Enterprises under the Conditions of the Czech Capital Market. In International Multidisciplinary Scientific Conference on Social Sciences and Arts SGEM2014 (pp. 93-98). http://dx.doi.org/10.5593/sgemsocial2014/ B22/S6.012

18. Kislingerová, E. et al. (2010). Podnik v časech krize. Praha: Grada

19. Koziol, C. (2006). When does single-source versus multiple-source lending matter? International Journal of Managerial Finance, 2 (1), 19-48. http://dx.doi.org/10.1108/1743913061 0646153

20. Mačí, J. (2015). Vývoj financování podniků v souvislosti s krizí: úvěr nebo dluhopis. In Sbornik recenzovaných prìspèvkì z mez̧inárodní konference Hradecké ekonomické dny 2015, díl II (pp. 175-181). Hradec Králové: Gaudeamus.

21. Machnes, Y. (2010). Weak signalling of bond ratings in Israel. European Business Review, 22 (2), 222-231. http://dx.doi.org/10.1108/09555341011023533

22. Meluzín, T. (2008). Problematika financování podniků prostřednictvím IPO na českém kapitálovém trhu. Ekonomika a Management, 2008 (4) 
23. Meluzín, T., \& Zinecker, M. (2009). IPO. Prvotni verejná nabidka akcií jako zdroj financování rozvoje podniku. Brno: Computer Press

24. Miles, W. (2000). The Pricing of Risk in Emerging Credit Markets: Bonds versus Loans. International Advances in Economic Research, 6 (2), 221-231. http://dx.doi.org/10.1007/ BF02296103

25. Miloš, D. (2004). Prerequisites and Constraints of Corporate Bond Market Development - Cross-Country Analysis. In Proceedings of the 2nd International Conference „An Enterprise Odyssey: Building Competitive Advantage (pp. 543-559), Zagreb: Ekonomski fakultet

26. Myers, S. C. (1984). The capital structure puzzle. The Journal of Finance, 39 (3), 575-592. http://dx.doi.org/10.1111/j.1540-6261.1984.tb03646.x

27. Nývltová, R., \& Režňáková, M. (2007). Męinárodni kapitálové trby: zudroj financování. Praha: Grada

28. Renaud, R. (2014). Why do companies issue debt and bonds? Can't they just borrow from the bank? Investopedia. Retrieved from http://www.investopedia.com/ask/answers/05/ reasonforcorporatebonds.asp

29. Smith, L. (2014). Why Companies Issue Bonds. Investopedia. Retrieved from http://www. investopedia.com/articles/investing/062813/why-companies-issue-bonds.asp

30. Sprčić, D. M., \& Wilson, I. (2007). The development of the corporate bond market in Croatia. EuroMed Journal of Business, 2 (1), 74-86. http://dx.doi.org/10.1108/14502190710749 965

31. Strýčková, L., \& Hojná, R. (2013). Is There a Space for an Innovative Approach to Sources of Business Financing in the Czech Republic? In Proceedings of the 11th International Conference Liberec Economic Forum (pp. 522-531). Liberec: Technická univerzita v Liberci

32. Užík, M., \& Šoltés, V. (2009). Vplyv zmeny ratingu na ceny spoločností obchodovaných na kapitálovom trhu. E+M Ekonomie a Management, 12 (1), 49-56

33. Yoshitomi, M., \& Shirai, S. (2001). Designing a Financial Market Structure in Post-Crisis Asia - How to Develop Corporate Bond Market (working paper 15). Tokyo: ADB Institute, 21 March. Retrieved September 23, 2015 https://openaccess.adb.org/bitstream/handle/11540/4120/2 001.03.rp15.corporate.bond.markets.pdf?sequence $=1$

\section{Contact information}

Ing. Jan Maři, Ph.D.

Technical University of Liberec, Faculty of Economics Voronězskéa 13, 46001 Liberec 1, Czech Republic

Email:jan.maci@tul.cz.

Ing. Vladimíra Hovorková Valentová, Ph.D.

Technical University of Liberec, Faculty of Economics

Voroně̌šská 13, 46001 Liberec 1, Czech Republic

Email:vladimira.valentova@tul.cz. 